\title{
Penggunaan Aplikasi Google Classroom Yang Dipadukan Dengan Aplikasi Google Meet Dalam Pembelajaran Daring Untuk Meningkatkan Hasil Belajar Siswa Pada Mata Pelajaran Ekonomi Materi Lembaga Jasa Keuangan Kelas X- IPS-1 di SMA Negeri 11 Banda Aceh
}

\author{
Aswanita Usman, S.Pd.,M.Pd \\ SMA Negeri 11 Banda Aceh
}

\begin{abstract}
Abstrak
Tujuan penelitian ini yaitu "untuk mengetahui Penggunaan Aplikasi Google Classroom yang di Padukan Dengan Aplikasi Google Meet dalam Pembelajaran daring Untuk meningkatkan Hasil Belajar Siswa pada Mata Pelajaran Ekonomi Materi Lembaga Jasa Keuangan Kelas X-Ips-1 Di SMA Negeri 11 Banda Aceh Pelajaran 2019/2020”. Penelitian ini dilakukan di SMA Negeri 11 Banda Aceh, pada bulan Agustus sampai dengan Nopember 2020. Subyek dalam penelitian ini adalah siswa kelas X- IPS -1 SMA Negeri 11 Banda Aceh yang berjumlah 29 siswa. Berdasarkan hasil analisis dan refleksi pada siklus I hasil belajar kognitif siswa yang mencapai nilai KKM hanya sebesar $44 \%$. Persentase ini tentu masih rendah dan harus diperbaiki pada siklus selanjutnya. Kemudian hasil belajar kognitif siswa yang mencapai nilai KKM hanya sebesar 44\% dari jumlah siswa, persentase ini belum menenuhi indikator keberhasilan yang ditetapkan yaitu $76 \%$ dari jumlah siswa mencapai nilai KKM. Persentase pada siklus I belum mencapai ketuntasan sehingga dilanjutkan siklus ke II. Terdapat peningkatan hasil belajar kognitif siswa pada siklus II ini. Pada siklus I jumlah siswa yang mencapai KKM hanya sebesar $44 \%$ dan pada siklus II meningkat menjadi $76 \%$ dan penggunaan aplikasi google classroom yang dipadukan dengan aplikasi google meet dalam pembelajaran daring dikatakan berhasil. Berdasarkan hasil analisis dan refleksi pada siklus II, maka dinyatakan bahwa ada peningkatan yang signifikan dari siklus I ke siklus II. Pada siklus II telah diperoleh data bahwa $76 \%$ dari jumlah siswa telah mencapai nilai KKM. Persentase tersebut sesuai dengan indikator keberhasilan yang diharapkan.
\end{abstract}

\section{Kata Kunci : Aplikasi, Google Classroom, Google Meet, Pembelajaran daring}

\section{PENDAHULUAN}

Covid-19 merupakan penyakit menular, yang berarti dapat menyebar, baik secara langsung maupun tidak langsung, dari satu orang ke orang lain. Kondisi ini menyerang sistem pernapasan seperti hidung, tenggorokan, dan paru-paru. Rumitnya penanganan wabah, belum ditemukannya vaksin dan obat untuk penyembuhan pasien Covid-19 serta terbatasnya alat pelindung diri (APD) untuk tenaga kesehatan membuat pemerintah menerapkan kebijakan ketat untuk memutus rantai penyebaran Covid-19. Salah satu cara untuk memutus mata rantai penyebaran Covid-19 adalah dengan melakukan pembatasan interaksi masyarakat yang diterapkan dengan istilah physical distancing.

Namun, kebijakan physical distancing tersebut dapat menghambat laju pertumbuhan dalam berbagai bidang kehidupan, baik bidang ekonomi, sosial, dan tentu saja pendidikan. Keputusan pemerintah untuk meliburkan para peserta didik, memindahkan proses belajar mengajar di sekolah menjadi di rumah dengan 
menerapkan kebijakan Work From Home (WFH) membuat resah banyak pihak. WFH adalah singkatan dari work from home yang berarti bekerja dari rumah.

Maka dari itu, pembelajaran tatap muka yang mengumpulkan banyak peserta didik di dalam kelas ditinjau ulang pelaksanaanya. Permbelajaram di kelas harus diselenggarakan dengan skenario yang mampu mencegah berhubungan secara fisik antara guru dengan peserta didik maupun peserta didik dengan peserta didik (Firman, F., \& Rahayu, S., 2020). Menurut Milman (2015) penggunaan teknologi digital dapat memungkinkan mahasiswa dan dosen melaksanakan proses pembelajaran walaupun mereka ditempat yang berbeda. Bentuk pembelajaran yang dapat dijadikan solusi dalam masa pandemi covid-19 adalah pembelajaran daring. Menurut Ali Sadikin. Dkk (2020) Pembelajaran daring merupakan pembelajaran yang menggunakan jaringan internet dengan aksesibilitas, konektivitas, fleksibilitas, dan kemampuan untuk memunculkan berbagai jenis interaksi pembelajaran.

Penggunaan Google Classroom ini sesungguhnya mempermudah guru dalam mengelola pembelajaran dan menyampaikan informasi secara cepat dan akurat kepada siswa (Hardiyana, 2015). Google Meet sendiri merupakan sebuah media pembelajaran menggunakan video. Dalam aplikasi Google Meet ini kita bisa berkomunikasi langsung dengan siapapun lewat video. Oleh karena itu, media ini memang cocok digunakan sebagai media pembelajaran. Penggunaan aplikasi Google Meet ini dapat membantu peserta didik lebih memahami materi yang mereka peroleh sebelumnya di Google Classroom, hal itu dikarenakan guru dan peserta didik dapat berinteraksi langsung untuk kegiatan tanya jawab ataupun berdiskusi secara audio dan visual serta mengadakan kegiatan presentasi di dalam web meeting tersebut.

Hal itulah yang mendasari penulis tertarik untuk mengadakan penelitian yang berjudul "Penggunaan Aplikasi Google Classroom yang di Padukan Dengan Aplikasi Google Meet dalam Pembelajaran daring Untuk meningkatkan Hasil Belajar Siswa pada Mata Pelajaran Ekonomi Materi Lembanga Jasa Keuangan Kelas X-Ips-1 Di SMA Negeri 11 Banda Aceh Pelajaran 2019/2020".

\section{Tujuan Penelitian}

Penelitian ini dilakukan untuk mencapai tujuan yang berkaitan dengan permasalahan yang telah dirumuskan. Tujuan penelitian ini adalah

1. Untuk mengetahui hasil belajar sebelum mengunakan aplikasi google classroom yang dipadukan dengan aplikasi google meet dalam pembelajaran daring mata pelajaran ekonomi di SMA Negeri 11 Banda Aceh.

2. Untuk mengetahui penggunaan aplikasi google classroom dan aplikasi google meet dalam pembelajaran daring mata pelajaran ekonomi di SMA Negeri 11 Banda Aceh.

3. Untuk mengetahui hasil belajar setelah mengunakan aplikasi google classroom yang dipadukan dengan aplikasi google meet dalam pembelajaran daring mata pelajaran ekonomi di SMA Negeri 11 Banda Aceh.

\section{LANDASAN TEORI}

\section{Pembelajaran Daring}

Dalam sebuah proses pembelajaran, peserta didik dapat melakukan proses pembelajaran secara mandiri ataupun secara kolaboratif. Dalam konteks pembelajaran online yang berlandaskan pada metode pembelajaran kolaboratif, penggunaan fasilitas komunikasi sangat di perlukan untuk mendukung interaksi antar peserta dalam proses pembelajaran. Penelitian pertama di lakukan dengan cara menguji hipotesis terhadap beberapa aspek di antaranya: analisa persepsi dari peserta didik (learners), mengenali 
kekuatan dan kelemahan dari penerapan eLearning, perbedaan yang signifikan di tinjau dari pencapaian akhir atau prestasi learners, dan metode yang di sarankan untuk diterapkan dalam pembelajaran berbasis e-Learning. Dari hasil penelitian tersebut disimpulkan bahwa e-Learning dan pengembangannya masih sangat diperlukan dan dikembangkan untuk memperkaya metode pembelajaran (Rengasamy Elango, dkk. 2009).

\section{Google Classroom}

Menurut Abdul Barir Hakim, Google Classroom adalah layanan berbasis Internet yang disediakan oleh Google sebagai sebuah sistem e-learning. Service ini didesain untuk membantu pengajar membuat dan membagikan tugas kepada pelajar secara paperless. Pengguna service ini harus mempunyai akun di Google. Selain itu Google Classroom hanya bisa digunakan oleh sekolah yang mempunyai Google Apps for Education. Dengan demikian Google Classroom merupakan suatu aplikasi yang disediakan oleh Google For Education untuk menciptakan ruang kelas dalam dunia maya. Aplikasi ini dapat membantu memudahkan guru dan siswa dalam melaksanakan proses belajar dengan lebih mendalam. Pembelajaran dengan menggunakan rancangan kelas yang mengaplikasikan Google Classroom sesungguhnya ramah lingkungan.

Hal ini dikarenakan siswa tidak lagi menggunakan kertas dalam mengumpulkan tuganya. Pemanfaatan Google Classroom dapat melalui multiplatform yakni melalui komputer dan telepon genggam. Guru dan siswa dapat mengunjungi situs https://classroom.google.com atau mengunduh aplikasi melalui playstore di android atau app store di iOS dengan kata kunci Google Classroom. Penggunaan LMS tersebut tanpa dipungut biaya, sehingga pemanfaatannya dapat dilakukan sesuai kebutuhan.

\section{Google Meet}

Google Meet terintegrasi dengan G Suite, yang memungkinkan pengguna untuk dapat bergabung langsung dari Kalender atau undangan yang dikirim via email. Selain itu, undangan meeting yang dibuat dari aplikasi tersebut juga dapat diakses melalui tautan dan kode rapat yang dikirimkan, serta nomor telepon jika tersedia. Pengguna yang menggunakan Skype for Business atau sistem berdasarkan standar SIP dan H.323 (Polycom dan Cisco) juga dapat dengan mudah bergabung dengan pertemuan Google Meet melalui Pexip Infinity Platform. Menariknya lagi, aplikasi ini juga dapat dinikmati melalui perangkat seluler, baik itu iOS maupun Android. Pengguna dapat pula memantau jadwal rapat dengan semua informasi penting dari Kalender layaknya versi desktop. Adapun cara untuk membuat undangan pertemuan tersebut yakni dengan membuat akun di G Suite. Anda akan diminta untuk memasukkan nama bisnis, pilih jumlah karyawan, dan isi data diri untuk menjadi admin G Suite.

\section{Hasil belajar}

Dalam lingkup demikian maka hasil belajar merupakan perolehan dari hasil proses belajar siswa yang dapat ditunjukan melalui kegiatan atau perilaku siswa tersebut dalam kehidupan seharihari. Dalam UU RI No. 14 Tahun 2005 tentang guru dan dosen diterangkan bahwa kompetensi merupakan seperangkat pengetahuan, keterampilan dan perilaku yang harus dimiliki, dihayati, dan dikuasai oleh seseorang. Jadi kompetensi bermakna perilaku yang muncul atau hasil yang muncul sebagai akibat proses pembelajaran. Menurut Syamsir Hidayat dkk dalam Jurnal penelitian pembelajaran fisika "perilaku dalam hal ini dapat berwujud pengetahuan (kognitif), 
keterampilan (psikomotor), dan sikap (afektif) yang terinternalisasi dalam diri seseorang".

\section{METODOLOGI PENELITIAN}

Lokasi dan Waktu Penelitian

Penelitian ini dilakukan pada bulan Agustus sampai dengan Nopember 2020 di SMA Negeri 11 Banda Aceh.

\section{Subjek Penelitian}

Subjek dari penelitian ini yaitu kelas X- IPS -1 SMA Negeri 11 Banda Aceh yang berjumlah 29 siswa.

\section{Objek Penelitian}

Objek penelitian ini adalah hasil belajar siswa dengan penggunaan Google Classroom dan Google Meet.

\section{Teknik Pengumpulan Data}

Dalam pelaksanaan penelitian ini teknik pengumpulan data dilakukan dengan pemberian LKPD saat kegiatan pembelajaran berlangsung serta pemberian test setelah pelajaran. Peneliti membuat post test yang dilakukan selesai pembelajaran menggunakan aplikasi Google Classroom dan aplikasi Google Meet. Hasil post test pada siklus kedua akan dibandingkan dengan hasil post test siklus pertama untuk mengetahui ada tidaknya peningkatan hasil belajar siswa. Test yang sudah saya buat ada di LKPD dan Evaluasi yang sudah saya susun sebelumnya yang disertai dengan rubrik penilaian.

\section{Instrument Penelitian}

Menurut Sugiyono (2013: 146) instrumen penelitian merupakan alat yang digunakan untuk mengukur variabel penelitian. Instrumen penelitian yang akan digunakan pada penelitian ini adalah Tes.

\section{HASIL PENELITIAN DAN PEMBAHASAN Deskripsi Hasil Penelitian \\ Siklus I}

\section{Tahap Perencanaan}

Pembelajaran disusun oleh peneliti yang berkolaborasi dengan guru mata pelajaran ekonomi yang yang akan melakukan tindakan. Penentuan materi yang dijadikan sebagai objek penelitian dibahas bersama guru mata pelajaran. Perencanaan dalam penelitian tindakan kelas pada siklus I adalah sebagai berikut:

a. Menyusun perangkat pembelajaran yang terdiri dari RPP, bahan ajar, LKPD, media pembelajaran, evaluasi sesuai dengan materi yang tertera pada silabus.

b. Bahan ajar dan media pembelajaran yang sudah disusun dan di unggah ke Google Classroom sebelum pembelajaran daring dimulai.

c. Menyusun Lembar Kerja Peseta Didik (LKPD) berupa soal-soal yang akan dikerjakan oleh setiap kelompok pada proses pembelajaran daring dengan penerapan model pembelajaran Discovery Learning. LKPD di unggah ke Google Classroom sebelum pembelajaran daring dimulai, dan diskusi kelompok dilakukan melalui Google Classroom. 
d. Menyiapkan evaluasi berupa soal pilihan ganda sebagai instrumen penelitian pada siklus ini. Soal dibuat dengan google form yang dikirim ke Google Classroom untuk mengukur hasil belajar kognitif siswa

e. Menyiapkan penilaian afektif berupa lembar observasi, penilaian kognitif berupa rubrik penilaian dan penskoran dan penilaian psikomotorik berupa rubrik penilaian dan penskoran.

f. Menyiapkan lembar observasi kegiatan pembelajaran daring yang akan dilakukan oleh observer yaitu teman sejawat.

g. Mempersiapkan peralatan seperti laptop, jaringan internet sebagai pendukung dalam pembelajaran daring.

h.

enyiapkan platform pembelajaran Google classroom, WAG kelas serta Google Meet

i. Menyiapkan ruangan yang akan digunakan untuk pembelajaran daring dan pelaksanaan tindakan siklus I pada penelitian tindakan kelas

j. Menyiapkan link Google dan link absensi kemudian mengirimkan nya kepada peserta didik untuk pembelajaran daring

2. Tahap Pelaksanaan Tindakan

Pelaksanaan tindakan siklus I berlangsung selama 2 x 45 menit. Pada tahap ini, guru melaksanakan pembelajaran daring dengan materi Otoritas Jasa Keuangan (OJK), sesuai dengan langkah-langkah model pembelajaran Discovery Learning yang terdapat pada RPP yang telah dibuat. Langkah-langkah pembelajaran tersebut adalah sebagai berikut :

a. Pendahuluan dilakukan melalui Google Classroom

- Guru membuka pelajaran dengan salam

- Berdoa dilakukan secara pribadi oleh siswa

- Guru memberi motivasi kepada peserta didik

- Guru mencek kehadiran peserta didik dengan membuat absensi dengan Google Form dan mengirimkan linknya ke Google Classroom

- Guru mengulang materi pelajaran minggu lalu

- Guru menyampaikan tujuan pembelajaran

b. Kegiatan inti (sesuai dengan langkah-langkah pembelajaran pada model Discovery Learning )

- Stimulation (memberi stimulus) dilakukan melalui Google Meet

Guru memberikan video pembelajaran dengan aplikasi youtube berupa video animasi dan peserta didik menginterpretasikan tayangan video tersebut dengan membuat catatan-catatan individual

- Problem Statement (mengidentifikasi masalah)

Peserta didik berpikir kritis dalam mengeksplorasi dan merumuskan penyelesaian masalah pada LKPD dilakukan melalui diskusi kelompok melalui Google Classroom

- Data Collecting (mengumpulkan data)

Peserta didik bekerja sama dan berdiskusi kelompok dalam mengumpulkan data melalui bahan ajar yang sudah dikirimkan dan sumber lainnya yang tersedia di internet. Diskusi kelompok dilakukan melalui Google Classroom

- Data Processing (mengolah data)

Peserta didik berdiskusi dalam mengolah data dan membuat kesimpulan sementara melalui diskusi kelompok di Google Classroom

- Verification (memverifikasi) 
Peserta didik mempresentasikan hasil diskusi kelompok dan membandingkan hasil diskusinya dengan kelompok lain, dilakukan melalui Google Meet. Hasil Diskusi berupa power point dikirimkan ke Google Classroom.

- Generalization (menyimpulkan)

Peserta didik bersama guru membuat kesimpulan yang disampaikan melalui Google Meet Meet dan memberikan evalusi berupa soal pilihan ganda sebanyak 10 butir soal dengan aplikasi Google Form dan dikirim ke Google Classroom.

c. Penutup dilakukan melalui Google Meet

- Guru melakukan refleksi bersama peserta didik tentang kegiatan pembelajaran yang sudah dilakukan

- Guru mengarahkan siswa untuk mengerjakan soal tes sebagai tolok ukur pencapaian pemahaman siswa terhadap materi yang telah disampaikan. Tes yang diberikan berupa soal pilihan ganda sebanyak 10 butir dalam bentuk Google Form

- Guru menyampaikan tindak lanjut dengan menyampaikan materi pembelajaran pertemuan berikutnya

- Guru menutup pelajaran dengan salam

3. Tahap Refleksi

Keberhasilan dan kelemahan dalam siklus I adalah sebagai berikut:

a. Secara keseluruhan, guru dan siswa telah mampu melaksanakan model Discovery Learning dengan baik.

b. Siswa masih kebingunan ketika pertama kali dijelaskan tentang model pembelajaran Discovery Learning. Hal ini diperbaiki dengan guru menjelaskan kembali sampai siswa benar-benar paham.

c. Pada fase Stimulation (memberi stimulus)

Pada fase ini Guru memberikan video pembelajaran dengan aplikasi youtube berupa cuplikan berita untuk merangsang daya fikir siswa tentang materi tersebut, peserta didik mengamati video tersebut dengan seksama, namun masih banyak siswa yang tidak dapat bergabung pada Google Meet yang dibuat pada fase ini

d. Problem Statement (mengidentifikasi masalah)

Pada fase ini masih banyak siswa yang belum mampu berfikir kritis tentang materi pembelajaran yang dilaksanakan

e. Data Collecting (mengumpulkan data)

Pada fase ini masih banyak siswa yang belum aktif berdiskusi dalam menyelesaikan LKPD yang telah diberikan guru

f. Data Processing (mengolah data)

Pada fase ini juga msih banyak siswa yang belum aktif berdiskusi

g. Verification (memverifikasi)

Pada bagian ini hanya sebagian siswa saja dari setiap kelompok yang aktif dalam melakukan presentasi hasil diskusi

h. Generalization (menyimpulkan)

Pada fase ini berjalan dengan baik guru dan siswa memberikan kesimpulan, dan guru memberikan penguatan dari materi pembelajaran yang sedang berlangsung. 
Analisis Data Skor Tes Hasil Belajar Siswa Pada Siklus I

\begin{tabular}{|c|c|c|c|c|c|c|c|c|c|}
\hline \multirow[t]{2}{*}{ No } & \multirow[t]{2}{*}{ Nama Siswa } & \multicolumn{5}{|c|}{ Item Soal } & \multirow[t]{2}{*}{ Jlh Skor } & \multirow[t]{2}{*}{ Nilai } & \multirow[t]{2}{*}{ Ket } \\
\hline & & 1 & 2 & 3 & 4 & 5 & & & \\
\hline 1 & Abdul Rahman Ritonga & 64 & 86 & 94 & 60 & 82 & 386 & 77 & $\mathbf{T}$ \\
\hline 2 & Agus Ferdiansyah & 74 & 79 & 98 & 64 & 72 & 388 & 78 & $T$ \\
\hline 3 & Agus Mulyadi B & 98 & 88 & 98 & 88 & 98 & 471 & 94 & $\mathbf{T}$ \\
\hline 4 & Ammaraya Duta Muhammad & 78 & 84 & 93 & 69 & 79 & 401 & 80 & $\mathbf{T}$ \\
\hline 5 & Arival Ibadi & 69 & 73 & 60 & 71 & 81 & 354 & 71 & $\mathbf{T}$ \\
\hline 6 & Aulia Syahputra & 67 & 81 & 91 & 72 & 60 & 371 & 74 & $\mathbf{T}$ \\
\hline 7 & Aulia Urrahman & 74 & 60 & 60 & 60 & 60 & 314 & 63 & TT \\
\hline 8 & Dhiaus Syauki & 76 & 60 & 87 & 60 & 60 & 343 & 69 & TT \\
\hline 9 & Facrurrazi & 63 & 60 & 60 & 60 & 60 & 303 & 61 & TT \\
\hline 10 & Fahrul Amri & 91 & 73 & 94 & 86 & 91 & 435 & 87 & $\mathbf{T}$ \\
\hline 11 & Mahadhitra Farizki & 60 & 60 & 60 & 60 & 60 & 300 & 60 & $\mathbf{T}$ \\
\hline 12 & M.ragil C.Pradana & 68 & 90 & 94 & 69 & 77 & 397 & 79 & $\mathbf{T}$ \\
\hline 13 & M.Kausar Nizam & 63 & 64 & 60 & 60 & 60 & 307 & 61 & TT \\
\hline 14 & M.Ishanul Hanif & 60 & 60 & 60 & 60 & 60 & 300 & 60 & TT \\
\hline 15 & Muhammad Ahlun uzuri & 94 & 98 & 98 & 98 & 82 & 470 & 94 & $\mathbf{T}$ \\
\hline 16 & Muhammad Fairuz Sahar & 67 & 60 & 60 & 60 & 60 & 307 & 61 & TT \\
\hline 17 & Muhammad Farhan & 69 & 95 & 93 & 64 & 75 & 394 & 79 & $\mathbf{T}$ \\
\hline 18 & Muhammad rizal & 61 & 60 & 60 & 60 & 60 & 301 & 60 & TT \\
\hline 19 & Muhammad rizki & 72 & 88 & 98 & 60 & 60 & 378 & 76 & $T$ \\
\hline 20 & Muhammad Syawal rizki & 60 & 72 & 87 & 62 & 60 & 342 & 68 & TT \\
\hline 21 & Mutaharrullah & 62 & 60 & 60 & 60 & 60 & 302 & 60 & TT \\
\hline 22 & Nasrullah & 60 & 60 & 60 & 60 & 60 & 300 & 60 & TT \\
\hline 23 & Rahmad Syukur & 60 & 60 & 94 & 60 & 60 & 334 & 67 & TT \\
\hline 24 & Riki aulia & 60 & 60 & 60 & 60 & 60 & 300 & 60 & TT \\
\hline 25 & Ridha Aditya S & 66 & 60 & 60 & 60 & 60 & 306 & 61 & TT \\
\hline 26 & Salman Alfarizi & 63 & 65 & 94 & 69 & 60 & 351 & 70 & $\mathbf{T}$ \\
\hline 27 & Sidiq masyawi & 67 & 64 & 94 & 60 & 60 & 345 & 69 & TT \\
\hline 28 & Syouki Mufiza & 60 & 60 & 60 & 60 & 60 & 300 & 60 & TT \\
\hline 29 & zakirullah & 80 & 80 & 80 & 82 & 95 & 417 & 83 & $\mathbf{T}$ \\
\hline & JUMLAH & & & & & & & 2043 & \\
\hline
\end{tabular}

Berdasarkan data skor perolehan siswa pada siklus I di atas, maka nilai setiap siswa pada tabel di atas diketahui jumlah nilai 2.043 dengan jumlah responden 29 orang, maka nilai rata-rata siswa yaitu 70,46. Dari 29 orang siswa yang mengikuti tes, ada 13 orang siswa yang mencapai batas $\mathrm{KKM}=70$ atau dinyatakan tuntas, dan 16 orang siswa yang dinyatakan tidak tuntas. Jadi persentase Ketuntasan belajar siswa pada siklus I adalah $44,82 \%$.

Berdasarkan hasil analisis dan refleksi pada siklus I hasil belajar kognitif siswa yang mencapai nilai KKM hanya sebesar $44 \%$. Persentase ini tentu masih rendah dan harus diperbaiki pada siklus selanjutnya. Kemudian hasil belajar kognitif siswa yang mencapai nilai KKM hanya sebesar 44\% dari jumlah siswa, persentase ini belum menenuhi indikator keberhasilan yang ditetapkan yaitu $75 \%$ dari jumlah siswa 
mencapai nilai KKM. Setelah tahap refleksi selesai maka keberhasilan dan kelemahan yang telah diuraikan di atas sebagai dasar pertimbangan penyusunan rencana tindakan yang akan dilaksanakan pada siklus II, harapannya adalah kekurangan yang terjadi pada siklus I tidak terulang kembali pada saat pelaksanaan siklus II.

\section{Siklus II}

\section{Tahap Perencanaan}

Pembelajaran disusun oleh peneliti yang berkolaborasi dengan guru mata pelajaran ekonomi yang yang akan melakukan tindakan. Penentuan materi yang dijadikan sebagai objek penelitian dibahas bersama guru mata pelajaran. Perencanaan dalam penelitian tindakan kelas pada siklus I adalah sebagai berikut:

a. Menyusun perangkat pembelajaran yang terdiri dari RPP, bahan ajar, LKPD, media pembelajaran, evaluasi sesuai dengan materi yang tertera pada silabus.

b. Bahan ajar dan media pembelajaran yang sudah disusun dan di unggah ke Google Classroom sebelum pembelajaran daring dimulai.

c. Menyusun Lembar Kerja Peseta Didik (LKPD) berupa soal-soal yang akan dikerjakan oleh setiap kelompok pada proses pembelajaran daring dengan penerapan model pembelajaran Discovery Learning. LKPD di unggah ke Google Classroom sebelum pembelajaran daring dimulai, dan diskusi kelompok dilakukan melalui Google Classroom.

d. Menyiapkan evaluasi berupa soal pilihan ganda sebagai instrumen penelitian pada siklus ini. Soal dibuat dengan google form yang dikirim ke Google Classroom untuk mengukur hasil belajar kognitif siswa

e. Menyiapkan penilaian afektif berupa lembar observasi, penilaian kognitif berupa rubrik penilaian dan penskoran dan penilaian psikomotorik berupa rubrik penilaian dan penskoran.

f. Menyiapkan lembar observasi kegiatan pembelajaran daring yang akan dilakukan oleh observer yaitu teman sejawat.

g. Mempersiapkan peralatan seperti laptop, jaringan internet sebagai pendukung dalam pembelajaran daring.

h. Menyiapkan platform pembelajaran Google classroom, WAG kelas serta Google Meet

i. Menyiapkan ruangan yang akan digunakan untuk pembelajaran daring dan pelaksanaan tindakan siklus I pada penelitian tindakan kelas

j. Menyiapkan link Google dan link absensi kemudian mengirimkan nya kepada peserta didik untuk pembelajaran daring

2. Tahap Pelaksanaan Tindakan

Pelaksanaan tindakan siklus I berlangsung selama 2 x 45 menit. Pada tahap ini, guru melaksanakan pembelajaran daring dengan materi Otoritas Jasa Keuangan (OJK), sesuai dengan langkah-langkah model pembelajaran Discovery Learning yang terdapat pada RPP yang telah dibuat. Langkah-langkah pembelajaran tersebut adalah sebagai berikut :

a. Pendahuluan dilakukan melalui Google Classroom

- Guru membuka pelajaran dengan salam

- Berdoa dilakukan secara pribadi oleh siswa

- Guru memberi motivasi kepada peserta didik

- Guru mencek kehadiran peserta didik dengan membuat absensi dengan Google Form dan mengirimkan linknya ke Google Classroom

- Guru mengulang materi pelajaran minggu lalu

- Guru menyampaikan tujuan pembelajaran 
b. Kegiatan inti (sesuai dengan langkah-langkah pembelajaran pada model Discovery Learning )

- Stimulation (memberi stimulus) dilakukan melalui Google Meet

Guru memberikan video pembelajaran dengan aplikasi youtube berupa video animasi dan peserta didik menginterpretasikan tayangan video tersebut dengan membuat catatan-catatan individual

- Problem Statement (mengidentifikasi masalah)

Peserta didik berpikir kritis dalam mengeksplorasi dan merumuskan penyelesaian masalah pada LKPD dilakukan melalui diskusi kelompok melalui Google Classroom

- Data Collecting (mengumpulkan data)

Peserta didik bekerja sama dan berdiskusi kelompok dalam mengumpulkan data melalui bahan ajar yang sudah dikirimkan dan sumber lainnya yang tersedia di internet. Diskusi kelompok dilakukan melalui Google Classroom

- Data Processing (mengolah data)

Peserta didik berdiskusi dalam mengolah data dan membuat kesimpulan sementara melalui diskusi kelompok di Google Classroom

- Verification (memverifikasi)

Peserta didik mempresentasikan hasil diskusi kelompok dan membandingkan hasil diskusinya dengan kelompok lain, dilakukan melalui Google Meet. Hasil Diskusi berupa power point dikirimkan ke Google Classroom.

- Generalization (menyimpulkan)

Peserta didik bersama guru membuat kesimpulan yang disampaikan melalui Google Meet Meet dan memberikan evalusi berupa soal pilihan ganda sebanyak 10 butir soal dengan aplikasi Google Form dan dikirim ke Google Classroom.

c. Penutup dilakukan melalui Google Meet

- Guru melakukan refleksi bersama peserta didik tentang kegiatan pembelajaran yang sudah dilakukan

- Guru mengarahkan siswa untuk mengerjakan soal tes sebagai tolok ukur pencapaian pemahaman siswa terhadap materi yang telah disampaikan. Tes yang diberikan berupa soal pilihan ganda sebanyak 10 butir dalam bentuk Google Form

- Guru menyampaikan tindak lanjut dengan menyampaikan materi pembelajaran pertemuan berikutnya

- Guru menutup pelajaran dengan salam

3. Tahap Refleksi

Keberhasilan dan kelemahan dalam siklus I adalah sebagai berikut:

a. Secara keseluruhan, guru dan siswa telah mampu melaksanakan model Discovery Learning dengan baik.

b. Siswa masih kebingunan ketika pertama kali dijelaskan tentang model pembelajaran Discovery Learning. Hal ini diperbaiki dengan guru menjelaskan kembali sampai siswa benar-benar paham.

c. Pada fase Stimulation (memberi stimulus)

Pada fase ini Guru memberikan video pembelajaran dengan aplikasi youtube berupa cuplikan berita untuk merangsang daya fikir siswa tentang materi tersebut, peserta didik mengamati video tersebut dengan seksama, namun masih banyak siswa yang tidak dapat bergabung pada Google Meet yang dibuat pada fase ini

d. Problem Statement (mengidentifikasi masalah)

Pada fase ini masih banyak siswa yang belum mampu berfikir kritis tentang materi pembelajaran yang dilaksanakan 
e. Data Collecting (mengumpulkan data)

Pada fase ini masih banyak siswa yang belum aktif berdiskusi dalam menyelesaikan LKPD yang telah diberikan guru

f. Data Processing (mengolah data)

Pada fase ini juga msih banyak siswa yang belum aktif berdiskusi

g. Verification (memverifikasi)

Pada bagian ini hanya sebagian siswa saja dari setiap kelompok yang aktif dalam melakukan presentasi hasil diskusi

h. Generalization (menyimpulkan)

Pada fase ini berjalan dengan baik guru dan siswa memberikan kesimpulan, dan guru memberikan penguatan dari materi pembelajaran yang sedang berlangsung.

Analisis Data Skor Tes Hasil Belajar Siswa Pada Siklus II

\begin{tabular}{|c|c|c|c|c|c|c|c|c|c|}
\hline \multirow[t]{2}{*}{ No } & \multirow[t]{2}{*}{ Nama Siswa } & \multicolumn{5}{|c|}{ Item Soal } & \multirow{2}{*}{$\begin{array}{l}\text { Jlh } \\
\text { Skor }\end{array}$} & \multirow[t]{2}{*}{ Nilai } & \multirow[t]{2}{*}{ Ket } \\
\hline & & 1 & 2 & 3 & 4 & 5 & & & \\
\hline 1 & Abdul Rahman Ritonga & 95 & 89 & 81 & 85 & 70 & 420 & 84 & $\mathbf{T}$ \\
\hline 2 & Agus Ferdiansyah & 75 & 76 & 90 & 93 & 72 & 405 & 81 & $\mathbf{T}$ \\
\hline 3 & Agus Mulyadi B & 98 & 95 & 81 & 92 & 88 & 454 & 91 & $\mathbf{T}$ \\
\hline 4 & Ammaraya Duta Muhammad & 83 & 79 & 94 & 88 & 80 & 423 & 85 & $\mathbf{T}$ \\
\hline 5 & Arival Ibadi & 98 & 95 & 73 & 60 & 73 & 399 & 80 & $\mathbf{T}$ \\
\hline 6 & Aulia Syahputra & 86 & 95 & 90 & 95 & 69 & 435 & 87 & $\mathbf{T}$ \\
\hline 7 & Aulia Urrahman & 86 & 85 & 90 & 85 & 67 & 412 & 82 & $\mathbf{T}$ \\
\hline 8 & Dhiaus Syauki & 89 & 85 & 81 & 60 & 60 & 376 & 75 & $\mathbf{T}$ \\
\hline 9 & Facrurrazi & 60 & 73 & 70 & 68 & 71 & 342 & 68 & TT \\
\hline 10 & Fahrul Amri & 98 & 98 & 94 & 90 & 77 & 457 & 91 & $\mathbf{T}$ \\
\hline 11 & Mahadhitra Farizki & 64 & 70 & 77 & 70 & 70 & 351 & 70 & $\mathbf{T}$ \\
\hline 12 & M.ragil C.Pradana & 83 & 98 & 94 & 91 & 72 & 439 & 88 & $\mathbf{T}$ \\
\hline 13 & M.Kausar Nizam & 66 & 76 & 64 & 73 & 65 & 344 & 69 & TT \\
\hline 14 & M.Ishanul Hanif & 60 & 76 & 65 & 60 & 63 & 324 & 65 & TT \\
\hline 15 & Muhammad Ahlun uzuri & 98 & 92 & 94 & 81 & 98 & 462 & 92 & $\mathbf{T}$ \\
\hline 16 & Muhammad Fairuz Sahar & 83 & 70 & 94 & 68 & 72 & 386 & 77 & $\mathbf{T}$ \\
\hline 17 & Muhammad Farhan & 80 & 76 & 90 & 73 & 90 & 409 & 82 & $\mathbf{T}$ \\
\hline 18 & Muhammad rizal & 65 & 73 & 63 & 70 & 68 & 338 & 68 & TT \\
\hline 19 & Muhammad rizki & 95 & 81 & 90 & 83 & 90 & 438 & 88 & $\mathbf{T}$ \\
\hline 20 & Muhammad Syawal rizki & 83 & 92 & 90 & 84 & 71 & 420 & 84 & TT \\
\hline 21 & Mutaharrullah & 65 & 68 & 63 & 77 & 65 & 338 & 68 & TT \\
\hline 22 & Nasrullah & 70 & 70 & 68 & 72 & 65 & 345 & 69 & TT \\
\hline 23 & Rahmad Syukur & 83 & 82 & 90 & 90 & 60 & 406 & 81 & $\mathbf{T}$ \\
\hline 24 & Riki aulia & 86 & 60 & 65 & 65 & 65 & 341 & 68 & $\mathbf{T}$ \\
\hline 25 & Ridha Aditya S & 92 & 85 & 90 & 63 & 72 & 402 & 80 & $\mathbf{T}$ \\
\hline 26 & Salman Alfarizi & 78 & 79 & 94 & 84 & 68 & 403 & 81 & $\mathbf{T}$ \\
\hline 27 & Sidiq masyawi & 86 & 85 & 98 & 87 & 72 & 428 & 86 & $\mathbf{T}$ \\
\hline 28 & Syouki Mufiza & 75 & 60 & 94 & 60 & 66 & 354 & 71 & $\mathbf{T}$ \\
\hline 29 & zakirullah & 80 & 80 & 80 & 82 & 95 & 417 & 83 & $\mathbf{T}$ \\
\hline \multicolumn{7}{|c|}{ JUMLAH } & & 2210 & \\
\hline
\end{tabular}

Berdasarkan data skor perolehan siswa pada siklus II di atas, maka nilai setiap siswa diketahui jumlah nilai 2.210 dengan jumlah responden 29 orang, maka nilai rata- 
rata siswa 76. Dari 29 orang siswa yang mengikuti tes, ada 22 orang siswa yang mencapai batas $\mathrm{KKM}=70$ atau dinyatakan tuntas, dan 7 orang siswa yang dinyatakan tidak tuntas. Jadi persentase Ketuntasan belajar siswa pada siklus II adalah 75.8\%.

a. Terdapat peningkatan hasil belajar kognitif siswa pada siklus II ini. Pada siklus I jumlah siswa yang mencapai KKM hanya sebesar 44\% dan pada siklus II meningkat menjadi $76 \%$ dan penggunaan aplikasi google classroom yang dipadukan dengan aplikasi google meet dalam pembelajaran daring dikatakan berhasil.

b. Berdasarkan hasil analisis dan refleksi pada siklus II, maka dinyatakan bahwa ada peningkatan yang signifikan dari siklus I ke siklus II. Pada siklus II telah diperoleh data bahwa $76 \%$ dari jumlah siswa telah mencapai nilai KKM. Persentase tersebut sesuai dengan indikator keberhasilan yang diharapkan.

\begin{tabular}{|c|c|c|c|c|c|c|}
\hline \multirow{2}{*}{ KETUNTASAN } & \multicolumn{2}{|c|}{ SIKLUS I } & \multicolumn{2}{c|}{ SIKLUS II } & \multicolumn{2}{c|}{$\begin{array}{c}\text { PERUBAHAN } \\
\text { SIKLUS I KE II }\end{array}$} \\
\cline { 2 - 7 } & F & $\mathbf{\%}$ & F & $\%$ & F & \% \\
\hline Tuntas & 13 Siswa & $44 \%$ & 16 Siswa & $55 \%$ & -11 Siswa & $-31 \%$ \\
\hline Belum Tuntas & 22 Siswa & $75 \%$ & 7 Siswa & $24 \%$ & 11 Siswa & $31 \%$ \\
\hline Jumlah & 29 Siswa & $100 \%$ & 29 Siswa & $100 \%$ & 0 Siswa & $0 \%$ \\
\hline
\end{tabular}

Peningkatan Hasil Belajar Kognitif Siswa pada Mata Pelajaran Ekonomi dengan "Penggunaan Aplikasi Google Classroom yang di Padukan Dengan Aplikasi Google Meet dalam Pembelajaran daring Untuk meningkatkan Hasil Belajar Siswa pada Mata Pelajaran Ekonomi Materi Lembanga Jasa Keuangan Kelas X-Ips-1 Di SMA Negeri 11 Banda Aceh Pelajaran 2020/2021".diketahui bahwa terjadi peningkatan hasil belajar kognitif siswa dari siklus I ke siklus II. Pada siklus II 75\% siswa telah mencapai nilai KKM, dibandingkan dengan siklus I mengalami peningkatan sebanyak 11 siswa atau $31 \%$ dari jumlah siswa. Persentase jumlah siswa yang mencapai nilai KKM pada siklus II menunjukkan adanya keberhasilan dalam proses pembelajaran yang berlangsung. Indikator keberhasilan pada penelitian ini adalah $75 \%$ dari jumlah siswa mencapai nilai KKM, pada siklus II telah diketahui bahwa $75 \%$ dari jumlah siswa telah mencapai nilai KKM, persentase tersebut telah sesuai dengan indikator keberhasilan yang ditetapkan. Penggunaan Aplikasi Google Classroom yang di Padukan Dengan Aplikasi Google Meet pada pembelajaran daring diharapkan dapat meningkatkan hasil belajar kognitif siswa. Pembelajaran kooperatif merupakan model pembelajaran dimana siswa membentuk kelompok diskusi, kegiatan diskusi ini diharapkan dapat membuat siswa menjadi lebih aktif walaupun dilaksanakan secara daring. Penggunaan Aplikasi Google Classroom yang di Padukan Dengan Aplikasi Google Meet dalam Pembelajaran daring varian dari media pembelajaran yang cocok digunakan untuk pembelajaran daring dimana setiap siswa dapat berdiskusi kelompok melalui Google Classroom untuk mendiskusikan tugas yang diberikan oleh guru. Secara keseluruhan pelaksanaan tindakan yang telah dilakukan dengan menggunakan model pembelajaran Discovery Learning berjalan sesuai dengan perencanaan yang telah disusun.

Berdasarkan hasil penelitian dan pengamatan yang telah diuraikan pada setiap siklusnya, maka hasil dari penerapan model pembelajaran Discovery Learning pada mata pelajaran ekonomi pada materi lembaga jasa keuangan dapat diuraikan sebagai berikut:

1. Proses Pembelajaran pada Mata Pelajaran Ekonomi pada materi lembaga jasa keuangan dengan Model Pembelajaran Discovery Learning penerapannya dalam penelitian tindakan kelas ini dilakukan mulai siklus I hingga siklus II. Adapun penerapan model pembelajaran

Discovery Learning pada mata pelajaran ekonomi adalah sebagai berikut 
a. Pada fase Stimulation (memberi stimulus)

Pada siklus I siswa mengamati video pembelajaran dengan seksama, namun masih banyak siswa yang tidak dapat bergabung pada Zoom Meet yang dibuat pada fase ini, untyk memperbaiki hal ini guru merekam pembelajaran pada saat Zoom Meet dan mengirimkannya ke Google Classroom, sehingga siswa yang tidak bisa bergabung tetap dapat mengikuti pembelajaran.

b. Problem Statement (mengidentifikasi masalah)

Pada siklus I masih banyak siswa yang belum mampu berfikir kritis tentang materi pembelajaran yang dilaksanakan, untuk memperbaikinya gurumemberikan stimulus yang lebih variatif dan menarik untuk merangsang daya kritis siswa.

c. Data Collecting (mengumpulkan data)

Pada siklus I masih banyak siswa yang belum aktif berdiskusi dalam menyelesaikan LKPD yang telah diberikan guru untuk memperbaiki hal ini guru memberikan waktu berdiskusi labih lama agar siswa termotivasi melihat keaktifan temannya, guru membimbing jalannya diskusi dan memberikan motivasi.

d. Data Processing (mengolah data)

Pada fase siklus I juga msih banyak siswa yang belum aktif berdiskusi untuk memperbaiki hal ini guru memberikan waktu berdiskusi labih lama agar siswa termotivasi melihat keaktifan temannya, guru membimbing jalannya diskusi dan memberikan motivasi.

e. Verification (memverifikasi)

Pada siklus I hanya sebagian siswa saja dari setiap kelompok yang aktif dalam melakukan presentasi hasil diskusi untuk memperbaiki hal ini guru memberikan motivasi dan penghargaan kepada siswa yang berani bertanya dan berani menjawab pertanyaan pada presentase berupa pemberian nilai tambah.

f. Generalization (menyimpulkan)

Pada fase ini siklus I tidak ada kendala sehingga pada siklus II tidak perlu ada perbaikan.

Berdasarkan data yang diperoleh setelah adanya penerapan model pembelajaran Discovery Learning pada siklus I telah dilaksanakan sesuai dengan perencanaan dan tahapannya, meskipun dalam pelaksanaannya masih terdapat beberapa hambatan. Hambatan-hambatan yang dialami segera direfleksik setelah pelaksanaan siklus I selesai, sehingga hambatan-hambatan yang dialami dapat diatasi pada pelaksanaan siklus II. Upaya-upaya perbaikan dilakukan oleh peneliti yang berkolaborasi dengan guru mata pelajaran ekonomi sehingga proses pembelajaran dengan menerapkan model pembelajaran Discovery Learning dapat berjalan dengan baik dan sesuai rencana. Agar kualitas pembelajaran lebih meningkat maka dilakukan upaya peningkatan pada pelaksanaan siklus II. Perbaikan dilakukan dengan menambah intensitas guru dalam memotivasi siswa dan guru lebih intensif dalam membimbing siswa yang mengalami kesulitan selama proses pembelajaran berlangsung. Proses pembelajaran dengan menerapkan model pembelajaran Discovery Learning pada mata pelajaran ekonomi dalam penelitian ini sudah baik dan dinyatakan berhasil mencapai indikator keberhasilan dalam meningkatkan hasil belajar kognitif siswa, sehingga tindakan dihentikan pada siklus II.

Dalam melaksanakan penelitian tindakan kelas ini terdapat keterbatasan yang mempengaruhi penelitian, antara lain sebagai berikut:

1. Penelitian ini hanya dibatasi pada penerapan model pembelajaran Discovery Learning pada mata pelajaran ekonomi pada materi lembaga jasa keuangan sebagai upaya peningkatan hasil belajar kognitif siswa. 
2. Hasil belajar kognitif hanya menunjukkan pada satu Kompetensi Dasar sehingga tidak dapat mencerminkan hasil belajar kognitif secara umum.

3. Tindakan hanya dilakukan satu kali pertemuan dalam satu siklusnya berdasarkan ijin yang diberikan oleh pihak sekolah tempat penelitian.

4. Kesulitan yang ditemukan observer dalam mengamati tindakan yang dilakukan peneliti karena kondisi jaringan, sehingga pada saat pembelajaran secara daring berlangsung banyak gangguan seperti suara tidak jelas, dan lain sebagainya.

5. Kondisi jaringan dan perangkat smartphone siswa merupakan hah-hal yangberada diluar jangkauan peneliti untuk mengatasinya.

\section{Kesimpulan}

Berdasarkan hasil analisis dan refleksi pada siklus I hasil belajar kognitif siswa yang mencapai nilai KKM hanya sebesar 44\%. Persentase ini tentu masih rendah dan harus diperbaiki pada siklus selanjutnya. Kemudian hasil belajar kognitif siswa yang mencapai nilai KKM hanya sebesar $44 \%$ dari jumlah siswa, persentase ini belum menenuhi indikator keberhasilan yang ditetapkan yaitu $75 \%$ dari jumlah siswa mencapai nilai KKM. Setelah tahap refleksi selesai maka keberhasilan dan kelemahan yang telah diuraikan di atas sebagai dasar pertimbangan penyusunan rencana tindakan yang akan dilaksanakan pada siklus II, harapannya adalah kekurangan yang terjadi pada siklus I tidak terulang kembali pada saat pelaksanaan siklus II. Terdapat peningkatan hasil belajar kognitif siswa pada siklus II ini. Pada siklus I jumlah siswa yang mencapai KKM hanya sebesar $44 \%$ dan pada siklus II meningkat menjadi $76 \%$ dan penggunaan aplikasi google classroom yang dipadukan dengan aplikasi google meet dalam pembelajaran daring dikatakan berhasil. Berdasarkan hasil analisis dan refleksi pada siklus II, maka dinyatakan bahwa ada peningkatan yang signifikan dari siklus I ke siklus II. Pada siklus II telah diperoleh data bahwa $76 \%$ dari jumlah siswa telah mencapai nilai KKM. Persentase tersebut sesuai dengan indikator keberhasilan yang diharapkan.

\section{DAFTAR PUSTAKA}

Ali Sadikin, Afreni Hamidah, (2020). Pembelajaran Daring di Tengah Wabah Covid19(Online Learning in the Middle of the Covid19 Pandemic) Program Studi Pendidikan Biologi FKIP, Universitas Jambi.

Firman, \& Rahayu, S. (2020). Pembelajaran online di tengah pandemi covid-19. Indonesian Journal of Educational Science, 2(2), 81-89

Hardiyana, Andri. 2015. Implementasi Google Classroom sebagai Alternatif dalam Meningkatkan Mutu Pembelajaran di Sekolah. Karya Tulis Ilmiah,

Milman, N.B (2015) Distance Education In International Encyclopedia of the Social \& Behavioral Science Secand Edition. https://doi.org10.1016/B978-0-08-0970868.92001-4

Rengasamy Elango, dkk. 2009). Penelitian kedua dengan judul penelitian "Aplikasi Penugasan Berbasis Web

Sugiyono. 2010. Metode Penelitian Pendidikan Pendekatan Kuantitatif, kualitatif, dan R\&D. Bandung: Alfabeta 